Гуманитарные ведомости ТГПУ им. Л. Н. Толстого № 4 (36), декабрь 2020 г.

НАУЧНЫЕ СООБЩЕНИЯ АСПИРАНТОВ

И МАГИСТРАНТОВ

\author{
В. В. Баженова \\ Кемеровский институт культуры
}

\title{
ОБРАЗЫ МИРОВОГО ДРЕВА И ДРЕВА ЖИЗНИ В РУССКОЙ КУЛЬТУРЕ
}

\begin{abstract}
Статья посвящена образу мирового древа в декоративно-прикладном искусстве, его символическое значение в языческие времена и древа жизни в христианской традиции.

Мировое Дерево является центральным символом славянской мифологии, обозначая неисчерпаемый источник жизненных сил и постоянно обновляющегося мира. Христианство вносит качественно новую трактовку Мирового Древа, побуждает людей взглянуть на мир другими глазами. И теперь уже это не Мировое Древо, а Древо Жизни. У христианских народов образ Древа ассоциируется с
\end{abstract} образом и символом креста.

Образ Мирового Древа обладает не только эстетической привлекательностью, но и оказывает определенное воздействие на нравственное и духовное развитие человека, на спасение его души. Древо Жизни является, по сути дела, своеобразной трансформацией христианского креста. Будучи элементом орнамента, Мировое Древо раскрывается в его содержательных связях с миром, с религиозным воззрением народа. В данной статье рассматривается содержательносмысловое значение Древа Жизни в русской православной традиции. Символ Древа Жизни выполняет функцию освобождения человека от поглощения мирской повседневностью, помогает ему осмыслить мир бытия, собственного предназначения, своего пути и своей цели в жизни, способствует соединению духовного и материального миров. Крест Господень есть символ распятого Христа и одновременно спасения человека и человечества.

Ключевые слова: Мировое Дерево, Древо Жизни, Крест Господень, христианство, крест, распятый Христос, страдание, вера, Спаситель, искупление.

V. V. Bazhenova

Kemerovo State University of Culture and Arts

(Kemerovo, Russia)

\section{THE IMAGES OF THE WORLD TREE AND THE TREE OF LIFE IN RUSSIAN CULTURE}

This article deals with the image of the World Tree in the applied art, its symbolism in pagan times and with the image of the Tree of Life in the Christian tradition.

The World Tree is the central symbol of Slavic mythology, denoting an inexhaustible source of vitality and a constantly renewing world. Christianity interprets the World Tree in a new way and encourages people to look at the world differently. Now it is not the World Tree but the Tree of Life. The Christians associate the Tree of Life with the image and the symbol of the cross.

The image of the World Tree is not only aesthetically appealing, but also it has a definite impact on the moral and spiritual development of a person, on the salvation of their soul. In its essence, the Tree of Life is a unique transformation of the Christian cross. As an element of ornaments, the World Tree is revealed in its meaningful links to the world and the religious values 
Гуманитарные ведомости ТГПУ им. Л. Н. Толстого № 4 (36), декабрь 2020 г.

of people. This article looks into the semantic meaning of the Tree of Life in the Russian Orthodox background. The symbol of the Tree of Life performs the function of freeing a person from being absorbed by the mundane everyday life, helps them to comprehend the world of being, their own destiny, their path and their goal in life, contributes to the connection of the spiritual and material worlds. The Holy Cross is a symbol of Christ crucified and at the same time, it is a symbol of salvation of a person and the humanity.

Keywords: World Tree, Tree of Life, Holy Cross, Christianity, cross, Christ crucified, suffering, belief, Saviour, redemption.

\section{DOI 10.22405/2304-4772-2020-1-4-113-124}

У каждого народа существует орнаментальное искусство, соответствующее его культуре. В орнаментальном искусстве многих стран и в русском народном искусстве часто встречается стилизованный образ Мирового Древа, пришедший из глубокой языческой древности. Да и само слово «древо» производно от слова «древнее» [4, с. 10]. В народном творчестве Мировое Древо - служит либо символом жизни (зеленое, цветущее), либо смерти (мертвое, засохшее).

Возникает вопрос: почему образ Древа встречается практически у всех народов, включая и русский? В языческие времена этот образ выполнял в основном функцию оберегов, защиты человека в физическом смысле и от злых духов. Несмотря на разнообразие вариантов Мирового Древа у разных народов, их смысловая нагрузка и символическое значение в основном совпадают. Например, у древних славян Мировое Древо - это символ, который соединяет повседневную жизнь с духовным миром. Древние славяне использовали символику Древа и для описания структуры мира. В их представлениях оно тесно связано с членением пространства по вертикали (небо - земля преисподняя). Таким образом, Мировое Древо как бы разделило мир на три яруса, где крона ассоциируется с Небом или небесным миром (правью), ствол с землей и человеческой реальной жизнью (явью), корни - с подземным океаном (навью) [1, с. 91]. В образе Мирового Древа запечатлена троичная система космогенеза, репрезентировавшая реальный мир из трех классов живых существ (птицы, животные, земноводные), из трех временных модусов (прошлое, настоящее, будущее), из трех частей тела (голова, туловище, ноги), из трех природных стихий (огонь, земля, вода) [8 c. 23]. Мировое Древо символ, сводящийся к единой оси. Важно отметить то, что «центральное место» (ствол) является зоной особой сакральности, так как является непосредственной связью трех основных пластов вертикальной иерархии мироустройства подземного, земного и небесного. Иначе говоря, «Мировая гора», «дерево» или «столб» предстают в качестве функции «оси», как главный конструктивный элемент этой связи, выполняющий коммуникативную задачу; эта «ось» одновременно и «лестница» между мертвыми, живыми и «высшими силами», потому что на «горе», «дереве» или «столбе» обитает «творец мира» (демиург). Таким образом, Мировое Древо соединяет все воедино и в результате становится осью и столпом, главной опорой мира [7, с. 54].

Мировое Дерево является центральным символом славянской мифологии, обозначая неисчерпаемый источник жизненных сил и постоянно 
Гуманитарные ведомости ТГПУ им. Л. Н. Толстого № 4 (36), декабрь 2020 г.

обновляющегося мира. Мировое Древо также является Древом Жизни и бессмертия. Мировое Древо, как символ всего живого, служило обозначением космического жизненного процесса, направленного из прошлого через настоящее в будущее. Корни этого древа находятся в прошлом, а крона - в будущем, ствол же - в настоящем [3, с. 420]. Мировое Древо - это код для обозначения определенных временных процессов. Образ Мирового Древа символ, помогавший древнему человеку проникнуть в суть объективной реальности, в явления повседневной жизни (рождение, жизнь и смерть), которые обрисовываются в форме пространственно-плоскостного или объемного образа - Древа. Вот почему древние славяне называли его Древом Жизни. Древо - символ развития. В образе Мировом Древа отражены представления человека о жизни, вечности, плодородии, благополучии, счастье [2, с. 10]. Память о связи Мирового Древа и времени зашифрована в старой загадке: «Стоит дуб, на дубу 12 сучьев, на каждом сучке по четыре гнезда, в каждом гнезде по семь птенцов». Так древние славяне давали мифическое изображение года: двенадцать месяцев, каждый из них содержит по четыре недели, а в неделе по семь дней [10, с. 142]. Мировое Древо стало также метафорическим образом сотворения мира. Из-под корней Древа вытекает источник духовной энергии. Птицы на ветвях Древа - символы душ и небесных посланников. С помощью Мирового Древа человечество поднимается от низшего уровня развития к духовному просветлению, спасению и освобождению из круга бытия.

Под сенью Мирового Древа протекают главные события, связанные как с зарождением мира, так и с дальнейшим ходом его развития. Это символ плодородия, связанный с обрядовым циклом сельскохозяйственных работ и культом великих матерей (богини-матери), отождествляется с книгой судьбы. Таким образом, Мировое Древо, в конечном счете, связывается с идеей абсолютной реальности и бессмертия.

В многочисленных школах русского народного искусства находим большое разнообразие стилизованных образов Мирового Древа. Это есть один из самых излюбленных образов в народном творчестве. Например, в мезенской росписи крона Древа написана в свернутом, еще не распустившемся виде, от основного ствола которого отходят отростки - ветви. В урало-сибирской росписи Мировое Древо написано в виде цветка или букета в горшке. В пермогорской, тоемской и других росписях Мировое Древо изображается как необычный, сказочный цветок с плодами. Изображая Мировое Древо, орнаментальный художник как бы шлет своему зрителю пожелания особой жизненной силы, продления рода, увеличения плодородия, юности и долголетия.

У христианских народов образ Древа ассоциируется с образом и символом креста, где вертикаль обозначает мироустройство, а горизонтальное членение древа связано с идеей жертвоприношения, с искупительной жертвой распятого Христа. 
Гуманитарные ведомости ТГПУ им. Л. Н. Толстого № 4 (36), декабрь 2020 г.

Христианство вносит качественно новую трактовку Мирового Древа, побуждает людей взглянуть на мир другими глазами. И теперь уже это не Мировое Древо, а Древо Жизни. Распятый на деревянном кресте Христос - это наиглавнейшая тема христианства. Христос умер на кресте, но и воскрес потом: так символ величайшего страдания превращается в символ спасения человека от смерти, страданий и греха и вечной блаженной жизни.

По библейским текстам Древо Жизни произрастает в Эдемском саду. Это был прекрасный и необычный сад, где было множеством деревьев, на которых росли плоды, этими вкусными плодами и питались первые люди: Адам и Ева. Среди многообразия райских деревьев были два особенных - Древо Жизни и Древо познания добра и зла. Плоды Древа Жизни предназначались для поддержания в сотворенном Богом человеке бессмертия. А Древо познания добра и зла, на вкушение плодов которых Господь наложил запрет, было предназначено для испытания свободы человека, его верности Богу, Который есть Любовь. Как известно, первые люди не выдержали испытания свободой, вкусили с Древа познания добра и зла, за что были удалены из Эдема, чтобы, став грешными, не вкусили плодов Древа Жизни и не стали бессмертными во грехе. Райское Дерево Жизни связывается с идеей абсолютной реальности и бессмертия. Канонической иконы с Древом Жизни нет ни в католической, ни в православной духовных традициях, поскольку в иконографии, как искусстве историческом, изображалось только то, что человек реально видел или узнал из Священного Предания.

Согласно же Преданию из библейского Древа Жизни был изготовлен крест, на котором и распяли Христа, а погребение Адама находится у самого подножия Голгофы. Этим можно объяснить изображение черепа и костей на православных распятиях. Символическое значение этого изображения можно найти в учении апостола Павла о Христе - новом Адаме «как в Адаме все умирают, Так во Христе все оживут» $[1$ Кор. 15, 22]. Крест Христов - это орудие спасения. Адам вкусил запретный плод от Древа познания добра и зла, что привело ко греху. Христос распят там, где был похоронен Адам, для того чтобы жизнь победила там, где когда-то смерть победила первого человека.

В 326 году царица Елена, мать императора Константина, отправляется в Иерусалим для поиска Креста Господня. После долгих поисков в одной из пещер под грудой мусора находят три креста. Чтобы узнать, который есть Крест Спасителя, стали возлагать эти кресты на тело умершего, ожившего только после прикосновения к нему третьим крестом. Таким образом, столб, на котором распяли Христа, был не просто орудием Его казни, он оказался Животворящим Крестом. После того как крест был обретен царицей Еленой, он находился в разных местах: в Иерусалиме, в Риме и Константинополе. Впоследствии священная реликвия стала разделяться и расходиться по христианскому миру. В 946 году при крещении в Константинополе, как благословение от патриарха, Святая равноапостольная княгиня Ольга получила крест с частицей Животворящего Древа, который находился, впоследствии, в алтаре Софийского собора в Киеве. К сожалению, в XVI веке эта священная 
Гуманитарные ведомости ТГПУ им. Л. Н. Толстого № 4 (36), декабрь 2020 г.

реликвия была вывезена поляками, и следы ее теряются. В современном Риме хранится большая часть Креста Господня. В церкви Иерусалимского Креста хранятся три фрагмента Креста Господня, один из Святых гвоздей и дощечка с надкрестной надписью на греческом, латинском и еврейском языках.

Крест - это центр мира; символ огня и света; символ распространяющегося света Истины; символ священного центра земли, где земная горизонталь пересекается с небесной вертикалью - эта точка встречи Неба с Землей. Крест - это символ страдания и веры, искупления и принятия смерти, мучения и жертвенности, спасения и вечного блаженства.

У первых христиан крест как орудие спасения мира был предметом глубокого почитания. Крест (по латыни - crux) - орудие для мучения, орудие пытки. Крест (по-гречески - ставрос) - столб, кол, любое деревянное сооружение, которое можно вбить или врыть в землю. Значит, первые христиане называли крестом столбы, на которых римские легионеры распинали преступников (непокорных рабов, грабителей, первых христиан). Причем столбы первоначально имели форму «Т» (трехчастный) и представляли собой простейшую конструкцию креста. Много позднее крест принял современную форму (перекладина спустилась до половины столба). Это произошло под влиянием сочетания древнего знака «Солнечного колеса» и буквы «Х» (квадратный, продолговатый или косой), начальной буквы имени Христа. В результате этого первый греческий христианский крест стал симметричным пересечением двух деревянных перекладин.

В 1011 году происходит раскол христианской Церкви на два религиозноцерковных направления - православие и католицизм. В связи с этим возникла необходимость различать эти две конфессии еще и по чисто внешним признакам. Так возникает новый вид креста католической церкви, который имеет одну сторону вдвое длиннее остальных С этого времени началась новая традиция: с появлением любого религиозного направления крест видоизменяется, возникают новые вариации его внешнего облика (увеличение перекладин, изменение силуэта его концов) [11, с. 113]. Известно большое многообразие форм крестов: равноконечные, кресты с более длинной

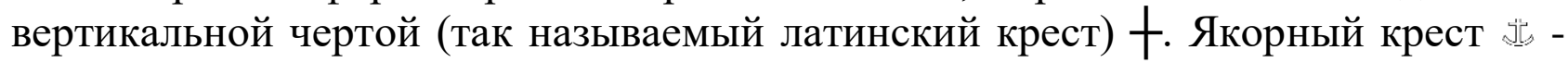
это «якорь» символизирует образ Церковного корабля, который по волнам бурной жизни переправляет желающих христиан к вечной жизни. Поэтому «якорь», ранее крестообразный, является «символом надежды на крепчайший плод Креста Христова» - Царствие Божие. Крест катакомбный, «знамение победы» $\{$. Катакомбные кресты четвероконечные использовались в катокомбах в период раннего христианства. Крест «Бургундский» или

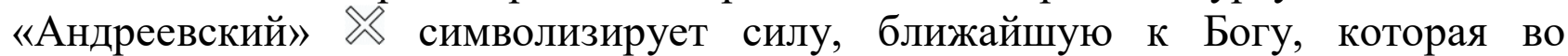
вселенной подобна букве «Х». Крест круглый «нахлебный» (8D. Еще с древности христиане надрезали выпекший хлеб крестообразно, для того, чтобы легко было разламывать. Ныне нахлебный крест изображается на потирах, фелонях и связаны с Таинством причащения, а сам хлеб - символ Тела Христова. 
Гуманитарные ведомости ТГПУ им. Л. Н. Толстого № 4 (36), декабрь 2020 г.

В православии преобладал крест восьмиконечный, отражая его сложную символику. Восьмиконечный крест символизирует жертву Христа и вечность (8 - знак вечности, знак Воскресения Христа после субботы - седьмого дня). Он включает в себя: вертикальный столб, поперечную перекладину, к которой были прибиты руки Христа, подставку для ног Его и доску над головой с надписью «Иисус Назарей Царь Иудейский». Вертикальный луч креста означает любовь и связь между Богом и человеком, горизонтальный - любовь и связь между людьми. Наклонное подножие символизирует схождение Христа в ад и выведение из глубин ада всех праведников, а также благоволение Спасителя к раскаявшемуся разбойнику, распятому по правую руку от Него [6, с. 53]. Четырехконечный крест знаменует собой четыре стороны света и Искупление всего человечества.

В православии имеется большое разнообразие накупольных крестов. Наиболее распространенным является крест «Крестным ветрилом окрылившийся корабль спасительный». Данный крест с подлунным подножием. Знак полумесяца рогами кверху символизирует победу креста над луною. Данный знак был принят в Византии как символ победы над язычеством. Есть еще одно значение этого символа: полумесяц - это корабль, ведомый кормщиком Христом. С древности православные храмы строились наподобие корабля, обращенного на восток. Церковь ведет верующих, не давая сгинуть в греховной пучине. Имеются и другие значения символа луны в накупольных крестах - это купель, Вифлеемские ясли, Евхаристическая Чаша. Русское православие находит разнообразные возможности пробуждать в верующих светлые и добрые чувства. Другой символ накупольного креста «Божественная лествица, ею же восходим на небеса», представляет ломаную линию в виде ступеней или лестницы на небеса. Это еще один символ спасительного Креста, выражение Божественной высоты и славы, небесной святыни.

Крест является главной святыней, как для православных так и для католиков. Но существуют явные отличительные признаки между ними [рис. 1]. Главное отличие заключается в форме креста и количестве его концов. В православии - шесть или восемь, в католической церкви - четыре. В православный крест иногда может добавляться нижняя перекладина с наклоном вниз справа «мерило праведное». На одной чаше весов - грехи человека, на другой - добрые и праведные дела. Но вера человека не зависит от этого, это всего лишь символ, который показывает приверженность к тому или другому религиозному учению. На католическом кресте изображён Христос с пальцами сложенными в кулак. Это символ тех мук, которые он перенес. Иногда на крестах изображена кровь, как символ нестерпимой боли и покаяния. На православном кресте Христос изображается с открытыми ладонями, словно Он принимает мир в Свои объятия. 
Гуманитарные ведомости ТГПУ им. Л. Н. Толстого № 4 (36), декабрь 2020 г.
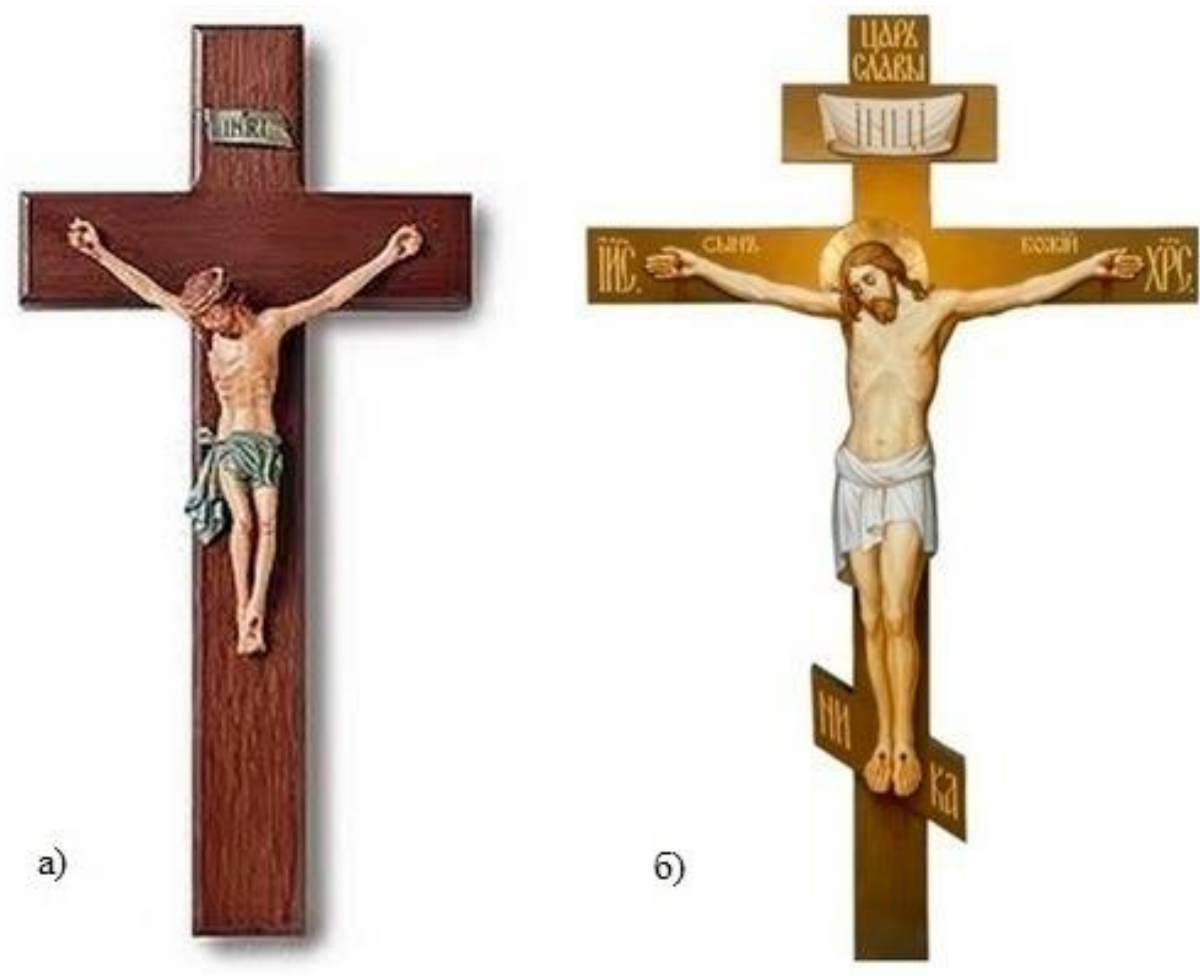

\section{Рис. 1. а) католический крест; б) православный крест}

Различие имеется и в табличке, которая расположена в верхней части креста. У православных на славянском языке это - ІНЦІ (либо IННІ, «Іисусъ Назарянинъ, Царь Іудейский»), а у католиков на латинице - INRI. На католическом кресте нет надписи: «Спаси и сохрани», а на православном данная надпись есть на оборотной стороне креста. На католических крестах ноги Христа прибиты одним гвоздем, на православном - двумя. При погребении умершего у православных крест устанавливают в ногах, у католиков же - у изголовья. На шпилях костелов устанавливают четырехконечные кресты, на православных храмах встречается многообразные формы крестов.

Католики уделяют особое внимание страстям Христовым. Страсти (анг. passion от латинского patio - «страдать», «претерпевать»). Из последних событий далеко не светских, а как явление духовное, стал фильм Мэлла Гибсона «Страсти Христовы». Фильм, который вызвал неоднозначное мнение различных кругов общественности: кинокритиков, клира и мирян, изображает последние часы земной жизни Иисуса. Главной целью фильма было явить зрителям величайшую трагедию и величайшую радость мира. Фильм чрезвычайно натуралистичен, отчего он крайне тяжел для восприятия зрителя. В православной традиции не принято делать акцент на теме распятия в столь детализированной и натуралистической форме. Фильм М. Гибсона «Страсти Христовы» адресовано современному зрителю, который привык к насилию и крови на экранах. Заставить людей плакать не сложно. Намного сложнее проникнуть в глубины его сердца, пробудить в нем веру и любовь. Поэтому изображения распятия в православии условны, можно сказать, выражены в 
Гуманитарные ведомости ТГПУ им. Л. Н. Толстого № 4 (36), декабрь 2020 г.

спокойных тонах (к примеру, у Дионисия): здесь главное не душевное возбуждение, а духовное прозрение человека.

Со времен средних веков известно такое явление в католической традиции как «стигматы». Это появление ран, подобие Христовых ран при распятии, на кистях, ступнях, лбу и боку. Первоначально стигматиками были только католики, но Божественное происхождение стигматов признавали чрезвычайно редко и проверялись тщательно специально созданной комиссией. Католики признают, что стигматы могут быть чудом. Стигматики почитаются как подвижники, избранные люди у Создателя. Иногда стигматики проходят процедуру канонизации. В отличие от католиков, православие отрицает стигматы, считает, что стигматы - это механическое подражание ранам Христа и не имеют смысла. Православная вера хочет видеть духовный подвиг и совершенствование человека, а стигматы - это проявление гордыни. Православие, по сравнению с католицизмом, в понятие «ношение язв Христовых» вносит другой смысл - символический. Ношение язв Христовых подразумевает: безграничную любовью к Богу, мученичество (например, у апостолов и христианских мучеников), добровольное «самоумерщвление» (заковывание себя железными поясами и веригами у монахов-схимников).

В XII в. опять же в католической церкви зарождается радикальное христианское движение - секта «флагеллантов». Движение считало, что искупить грехи можно самоистязанием. Они самобичевали себя, подражая избиению Христа. Самобичевание или «умерщвления плоти» достигло наивысшего расцвета во время эпидемии чумы. Флагелланты считали чуму Божьей карой и старались тем самым умягчить гнев Бога. Папа Римский запретил подобную практику «умерщвления плоти», но флагелланты еще долго продолжали существовать. У католиков самобичевание практикуется до сих пор. Православие не одобряет подобные «подвиги». Самобичевание не принято православной Церковью, и не принято это явление как оценка святости. Святость - это стремление к Богу, проявление любви к Нему и к человеку. Святость - это любовь и смирение. Самобичевание - это достижение экзальтации, нездорового духовного и психического состояния путем физического воздействия на своё тело или эйфория. Экзальтация очень далека от духовного просветления, это абсолютно разные понятия. Духовное просветление достигается созерцанием, глубокой молитвой и внутренней тишиной. Тихость веры, тихость Православия - это отличительная черта подлинной святости.

Крест мук Господних был изготовлен из четырех древесных пород: кедра, кипариса, маслины и пальмы. В этом сочетании древесных пород заложена символика четырех сторон света, т.е. пространственной ориентации. В силу этого крест стал важнейшим атрибутом христианских таинств литургии и крещения. Он теснейшим образом связан с исцелением и чудотворными силами, а также может защитить от бесов. Православные христиане носят нательный крест только под одеждой, на груди, как символ единения с Иисусом Христом. Крест, на котором Христос умер за людей, стал знаком христианской 
Гуманитарные ведомости ТГПУ им. Л. Н. Толстого № 4 (36), декабрь 2020 г.

веры, символом победы над смертью и спасения человека. Это же символическое значение несут и кресты на куполах христианских храмов. А если вспомнить Светлое христово Воскресение (Пасха) - самый главный православный праздник. А слова «Христос воскресе!» значат спасение и победа, преодоление материи. «Ибо божественный совершенный дух не подчинен материи, и любое страдание ради Христа увенчивается победой, а все доброе должно страдать, чтобы воскреснуть» - писал И. А. Ильин [5, с. 91]. В песнопениях православия праздник Пасхи называют: «Праздников праздник и торжество торжеств». В этот день отмечают торжество состоявшегося спасения и победы Божественной Любви над смертью. Людям был указан Христом путь спасения мира и каждого отдельно взятого человека через веру в Господа и следование за Ним. В православной традиции также каждое воскресенье считается праздничным днем в честь Воскресения Спасителя. Считается, что до Воскресения Христова даже праведники находились в аду, а их освобождение было совершено Спасителем.

Крест стал символом высочайшей чести и славы, символом искупительной благодати. Христос нес свой крест и допустил распять себя на нем для спасения всего рода человеческого, но сказал, что: «никто не может быть его учеником, если не последует за ним, неся свой крест». Это значит, что нужно вести борьбу с грехами, на которые толкает диавол. Чтобы спастись от его происков верующие ищут спасение в кресте, читают Молитву Животворящему Кресту: «Спаси, Господи, люди Твоя и благослови достояние Твое, победы на сопротивныя даруя, и Твое сохраняя Крестом Твоим жительство» [12, с. 82]. Крест у каждого человека свой, крест скорби и страдания земной жизни. При распятии на кресте Христос переживает страдания всего мира и всю адскую мощь греха уничтожает, прежде всего, в Самом Себе. В результате происходит победа над грехом. Смерть бессильна перед Спасителем, она не может взять Его душу. Богочеловек Сам желает принять кончину. Своей смертью Всесильный показывает Свою любовь к человеку. Е. Н. Трубецкой писал: «Совершенная жертва Христова спасает человека не как действующее извне колдовство, а как духовное воздействие, освобождающее его природу, лишь при условии самостоятельного самоопределения его воли» [13, с. 245]. Смерть Спасителя не была торжеством смерти, хотя Он умер как человек. Но Богочеловек принимает эту смерть для того, чтобы окончательно разрушить ее господство.

К теме Живого Древа и Креста Господня обращались также русские философы Серебряного века. Так, например, Е. Н. Трубецкой в своей книге «Смысл жизни» писал: «Раз сочетались в мире два начала - Бог стал человеком и понес его крестную муку, а человек стал сыном Божиим, тем самым весь мир осенен животворящим крестом, оба жизненные пути его наполнились смыслом - и путь горизонтальный, в пределах земного плана, и путь вертикальный подъем и высший план» [9, с. 49]. Далее Е. Н. Трубецкой утверждал, что ни одна отдельно взятая линия не может быть оправдана. Только в скрещении этих двух линий находится оправдание жизни. Смысл жизни над бессмыслицей 
Гуманитарные ведомости ТГПУ им. Л. Н. Толстого № 4 (36), декабрь 2020 г.

проходит через стирание грани между потусторонним и посюсторонним. Это и было совершено на кресте. Совершенная жертва являлась упразднением грани. Гранью являлось то, что сердце человека было закрыто для благодати. А сердце человека - это отражение земли. Сама земля закрылась от благодати. И чтобы она вновь открылась, нужно было совершить переворот в душе человека. «Душа должна была отдаться Богу безгранично, беззаветно, всей полнотой своей жизни и воли. Когда Сын человеческий принес Богу эту совершенную жертву, человеку отворились небеса и высшая тайна мирового смысла стала явной на земле. Обе линии человеческой жизни разом преисполнились божественной силы. - Крест стал животворящим. - Тут разрешение всей мировой скорби, тот яркий свет смысла, коим разом озаряются бесчисленные круги жизни природы и человечества» [14, с. 59]. Значение креста в христианстве огромно. Крест как явление совершенной Божественной любви, символ Вечной жизни. Он оберегает от бесов и нечистой силы.

Православная церковь 27 сентября установила в праздник Воздвижения Креста Господня поклоняться Честному и Животворящему кресту, на котором Господь и Спаситель перенес величайшие страдания ради нашего спасения. Праздник входит в число двунадесяти (главных) праздников, потому что Крест Господень - это не только предмет, связанный с жизнью и казнью Иисуса Христа, но и орудие Искупления Спасителем греха человека. Крест Господень стал средством спасения и символом спасения человека. Во время всенощной службы этого праздника на середину храма выносят крест, поклоняются и поют: «Кресту твоему поклоняемся, Владыко, и святое Воскресение Твое поем и славим». А в соборных храмах и монастырях поклонению кресту предшествует его воздвижение - крест медленно и высоко поднимают три раза. «На этом Кресте, по словам церковных песнопений, «смерть умерщвляется», для нас Крест Христов - божественная лестница, «ею же восходим на небеса»; спасительное древо - «орудие мира, непобедимая победа». Теперь для христиан «Крест - хранитель всея вселенныя; Крест - красота Церкви; Крест - царей держава; Крест - верных утверждение; Крест - ангелов слава и демонов язва. Очень хорошо кресты просматриваются в христианских храмах, убранстве алтарей, в церковных облачениях, в резьбе, на храмовых куполах. В архитектурных сооружениях храмов взят принцип организации храмового пространства и главных несущих опорных конструкций по типу креста с возведением в центре купола. План здания расчленяется крестом с перекрещением в центре. Подобную конструкцию имеют многие храмы на Руси. Например, храм Покрова Пресвятой Богородицы на Нерли, Собор Василия Блаженного в Москве, Успенский собор Московского Кремля. В быту крест как символ воспринимается еще и как один из самых действенных оберегов. Например, особо верующие, соля еду, творят одновременно крестное знамение, как бы неся на пищу частицу Божественной благодати.

Таким образом, образ Мирового Древа, часто встречающийся в орнаментальном искусстве разных народов, включая и русский, претерпел значительную эволюцию: от языческих представлений, служа главным образом 
Гуманитарные ведомости ТГПУ им. Л. Н. Толстого № 4 (36), декабрь 2020 г.

оберегом людей от жизненных опасностей и действий злых духов, - до образа Древа жизни в библейской традиции и животворящего Креста Господня в христианстве. В католической и православной духовных традициях сложились разные акценты в восприятии и переживания Креста Господня, наложив глубокий отпечаток на своеобразие западноевропейской и русской духовной культуры.

\section{Лumepamypa}

1. Баешко Л. С., Гордиенко А. Н., Гордиенко А. Н. Энциклопедия символов. М.: Эксмо, 2007. 91 с.

2. Вишневская В. М. Резьба и роспись по дереву. Петрозаводск: Карелия, 1981. 10 с.

3. Демин В. Н. Тайны русского народа: в поисках истоков Руси. М.: Вече, 2000. $420 \mathrm{c}$. $10 \mathrm{c}$.

4. Жегалова С. К. Русская народная роспись. М.: Просвещение, 1984.

5. Ильин И. А. Сущность и своеобразие русской культуры. М.: Русская книга - XXI век, 2007. 91 с.

6. Ионина Н. А. Православные святыни. М.: РООССА, 2010. 53 с.

7. Каширина Т., Евсеева Т. Символы. Знаки. М.: Аванта +, 2007. 54 с.

8. Кошаев В. Б. Композиция в русском народном искусстве. М.: Владос, 2006. 23 с.

9. Кулешов А. Печной комплекс в интерьере // Ремесла и промыслы. 2000. № 10. 49 c.

10. Могила О. А., Чумаков С. В. Я познаю мир. Скандинавские и германские страны, славянские страны, Индия, Китай, Япония. М.: АСТ, 2001. $142 \mathrm{c}$.

11. Похлебкин В. В. Международная символика и эмблематика. М.: Междунар. отношения, 1989. 113 с.

12. Слободский Серафим (протоиерей). Закон Божий. М.: Изд-во Сретенского монастыря, 1987. 82 с.

13. Трубецкой Е. Н. Избранные произведения. Ростов н/Д: Феникс, 1998. $245 \mathrm{c}$.

14. Трубецкой Е. Н. Смысл жизни. М.: Республика, 1994. 59 с.

\section{Refrences}

1. Baeshko L. S., Gordienko A. N., Gordienko A. N. Entsiklopediya simvolov [Encyclopedia of symbols]. Moscow: Eksmo Publ., 2007. 91 p. [In Russian]

2. Vishnevskaya V. M. Rez'ba i rospis' po derevu [Carving and painting on wood]. Petrozavodsk: Kareliya Publ., 1981. 10 p. [In Russian]

3. Demin V. N. Tayny russkogo naroda: v poiskakh istokov Rusi [Secrets of the Russian people: in search of the origins of Russia]. Moscow: Veche Publ., 2000. 420 p. [In Russian] 
Гуманитарные ведомости ТГПУ им. Л. Н. Толстого № 4 (36), декабрь 2020 г.

4. Zhegalova S. K. Russkaya narodnaya rospis' [Russian folk painting]. Moscow: Prosveshchenie Publ., 1984. 10 p. [In Russian]

5. Il'in I. A. Sushchnost' i svoyeobraziye russkoy kul'tury [Ilyin I. A. Essence and originality of Russian culture]. Moscow: Russkaya kniga - XXI vek Publ., 2007. 91 p. [In Russian]

6. Ionina N. A. Pravoslavnyye svyatyni [Orthodox shrines]. Moscow: ROOSSA Publ., 2010. 53 p. [In Russian]

7. Kashirina T., Evseeva T. Simvoly. Znaki [Symbols. Signs]. Moscow: Avanta + Publ., 2007. 54 p. [In Russian]

8. Koshaev V. B. Kompozitsiya v russkom narodnom iskusstve [Composition in Russian folk art]. Moscow: Vlados Publ., 2006. 23 p. [In Russian]

9. Kuleshov A. Pechnoy kompleks $v$ inter'yere [Furnace complex in the interior]. Remesla i promysly. 2000, Issue 10. 49 p. [In Russian]

10. Mogila O. A., Chumakov S. V. Ya poznayu mir. Skandinavskiye i germanskiye strany, slavyanskiye strany, Indiya, Kitay, Yaponiya [I discover the world. Scandinavian and Germanic countries, Slavic countries, India, China, Japan]. Moscow: AST Publ., 2001. 142 p. [In Russian]

11. Pokhlebkin V. V. Mezhdunarodnaya simvolika i emblematika [International symbols and emblems]. Moscow: Mezhdunarodnyye otnosheniya Publ., 1989. 113 p. [In Russian]

12. Slobodskoy Seraphim (archpriest). Zakon Bozhiy [The law of God]. Moscow: Izdatel'stvo Sretenskogo monastyrya Publ., 1987. 82 p. [In Russian]

13. Trubetskoy E. N. Izbrannyye proizvedeniya [Selected works]. Rostov-onDon: Feniks Publ., 1998. 245 p. [In Russian]

14. Trubetskoy E. N. Smysl zhizni [Meaning of life]. Moscow: Respublika Publ., 1994. 59 p. [In Russian]

Статья поступила в редакиию 17.11.2020

Статья допущена к публикаџии 14.12.2020

The article was received by the editorial staff 17.11.2020

The article is approved for publication 14.12.2020 